\begin{tabular}{|c|c|} 
Available online at: http://ejournal-balitbang.kkp.go.id/index.php/ifrj \\
e-mail:ifrj.puslitbangkan@ gmail.com \\
INDONESIANFISHERIESRESEARCHJOURNAL \\
Volume 24 Nomor 1 June 2018 \\
p-ISSN: 0853-8980 \\
e-ISSN: 2502-6569
\end{tabular}

\title{
FISHERIES SANCTUARY PLANNING IN PRACTICE: LESSON LEARNT FROM ECOSYSTEM APPROACH TO FISHERIES MANAGEMENT IN NORTH KALIMANTAN PROVINCE
}

\author{
Andhika Prima Prasetyo*1, Asep Priatna ${ }^{2}$, Agus Setiyawan¹, Rodo Lasniroha ${ }^{3}$, Fadli Yahya², Dian Oktaviani ${ }^{1}$, \\ Duto Nugroho', Rudy Masuswo Purwoko ${ }^{1}$, Nurmayanti ${ }^{4}$, Ersant Dirgantara ${ }^{4}$, Hendri Antoro ${ }^{5}$ and Dahlan Burikki ${ }^{6}$ \\ ${ }^{1}$ Center for Fisheries Research, Ministry for Marine Affairs and Fisheries, Balitbang KP 2 Building $3^{\text {rd }}$ floor, Pasir Putih II st., \\ Pademangan, Jakarta Utara, Indonesia \\ ${ }^{2}$ Research Institute for Marine Fisheries, Ministry for Marine Affairs and Fisheries, Raya Bogor Km 47st., Nanggewer Mekar, \\ Cibinong, Bogor, Indonesia \\ ${ }^{3}$ Institute for Coastal and Marine Resource Management Denpasar-Technical Unit in Kupang, Yos Sudarso st., Alak, Kupang \\ East Nusa Tenggara, Indonesia \\ ${ }^{4}$ Food, Agriculture and Fisheries District Office of Tarakan City, Gadis 2 Building $2^{\text {nd }}$ floor, Jend Sudirman st. no. 76, Tarakan, \\ North Kalimantan, Indonesia \\ ${ }^{5}$ Climatology Station of Bogor, Tambakan st., Situ Gede, Bogor, West Java, Indonesia \\ ${ }^{6}$ Fisher community elder in Tarakan City, Juata Laut, Tarakan Utara, Tarakan, North Kalimantan, Indonesia \\ Received; November 16-2017 Received in revised from May 22-2018; Accepted May 31-2018
}

\begin{abstract}
Governor Decree of North Kalimantan No. 26 in 2014 concerning Management of Bombay Duck in the North Kalimantan Province Waters was established in order to address over-exploitation of bombay duck (Harpadon nehereus) population. Fisheries sanctuary is the feasible solution that was agreed by comprehensive stakeholder discussion. This research aims to extract and elaborate our experiences on establishing fisheries sanctuary in the Bangkudulis waters which focus on science communication and in the fisheries sanctuary planning. The acoustic and larva survey conducted to support the consensus and to proof the traditional ecological knowledge of the communities. The results showed that the proposed conservation area of the Bangkudulis waters has significant ecological function to ensure the sustainability of bombay duck population. The distribution and abundance of larva and juveniles were found higher in that area. The approach and challenges to deal with ecological and socio-economic aspects as well as recommendations were discussed in this paper.
\end{abstract}

Keywords: EAFM; MPA; fisheries sanctuary; community engagement; science communication; Tarakan; North Kalimantan Province

\section{INTRODUCTION}

In 2014, Governor of North Kalimantan issued Governor Decree No. 26 concerning the management of bombay duck (Harpadon nehereus (Hamilton, 1822); Harpadontinae; Synodontidae) fisheries in the North Kalimantan Province's waters. It was also followed by Mayor Decree of Tarakan City No. 24 concerning the management of bombay duck fisheries in the Tarakan City's waters. Those regulations were the outcome of the initiation of Ecosystem Approach to Fisheries Management (EAFM) in 2012-2014 (Prasetyo et al., 2014). The consensus agreed on the priority of fisheries is to improve the living conditions of small-scale fishermen and fish farmers by establishing spatial closure of the area that suspected as nursery ground (Prasetyo et al., 2014). The regulation instructed to establish Fisheries Sanctuary in the Bangkudulis waters $(9,730$ ha) to ensure the sustainability of fisheries. Moreover, North Kalimantan Province established in 2012 is the youngest province in Indonesia (Constitution No. 20 in 2012 concerning the establishment of North Kalimantan Province), therefore a proper management should be supported intensively.

The regulation recognized that bombay duck (locally called as "nomei" or "pepija") is important resource generating economic benefits to the local community (Laga et al., 2015). The official record was limited to explore the significant benefit of Bombay duck to local community due lack of resources of local government. However, rapid assessment conducted during three years research found that more 
than 5,000 people relied on this resource from fishers, fisher's wife (processing), middleman, boat maker and trader in North Tarakan Sub-district (RCFMC, 2014).

This resource has been exploited historically by trawl fisheries in the certain period (two separate periods in a month about 7-10 days per period). The exploitation rate of the resources has been exceeded the sustainable level by $0.80 /$ year (Laga, 2015). The selection of the proposed sanctuary was agreed through intensive community engagement by setup serial focus group discussion (Prasetyo et al., 2014) and an extensive survey (acoustic and larvae survey) to support and proofed an anecdotal information. Oktaviani et al. (2016) stated the importance of acknowledging and enriching an anecdotal information (emic or traditional knowledge) with an empirical knowledge (etic) to preserve our valuable knowledge.

In coastal marine systems, ( Marine Protected Areas (MPAs) are being used as an approach to conserve biodiversity or maintain sustainable fisheries (Fogarty \& Botsford, 2007; Wood et al., 2008). The optimal design may differ on the MPAs that were created for biodiversity conservation and fishery management (Botsford et al., 2009; Halpern, 2003), but they have a common - ensuring the persistence of populations. Moreover, in designing MPA the connectivity is both crucial and questionable (Halpern et al., 2006), therefore further study need to be conducted to address it. Ecological and socioeconomic aspect is one of major challeges to establish the MPA, especially in the developing countries
(Christie, 2004; Crawford et al., 2006; Elliott et al., 2001). It also required regulation as an umbrella of implementation (Mous et al., 2005).

This research is aimed to extract and elaborate our experiences on establishing fisheries sanctuary in the Bangkudulis waters which focus on science communication and in the fisheries sanctuary planning. It consists of (1) to gather the best available information (empirical and anecdotal sources) and (2) elaborate the information and proofed by scientific approach.

\section{MATERIALS AND METHODS Time and Location}

Exploratory survey was conducted in two periods (May 2012 and May 2014) in the Bangkudulis and Juata Laut waters ( $\left.3^{\circ} 27^{\prime} 2.78^{\prime \prime} \mathrm{N} 117^{\circ} 23^{\prime} 12.55^{\prime \prime} \mathrm{E}\right)$; northwest of Tarakan island (Figure 1). Those two period of survey collected similar parameter and complimentary of each cruise for comprehensive analysis (an average value) by assuming similar characteristic, resources and fishing pressure. Those locations were selected through an extensive discussion with representative key stakeholders (Prasetyo et al., 2014). This initial information was an anecdotal information that stated Bangkudulis waters were the nursery ground of bombay duck (Figure 2 and Figure 3). Those sampling areas mostly consist of muddy substrate and surrounded by mangrove and nipa forest. This area mainly affected by fresh water supply from upstream, especially during rainy season (September to January).

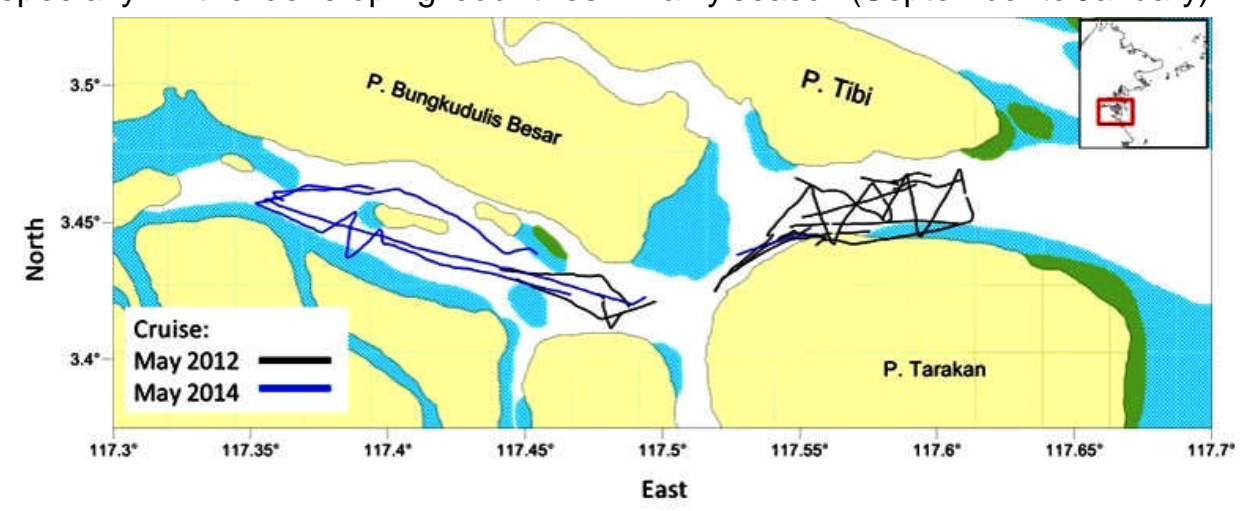

Figure 1. Location of research; track of acoustic acquisition.

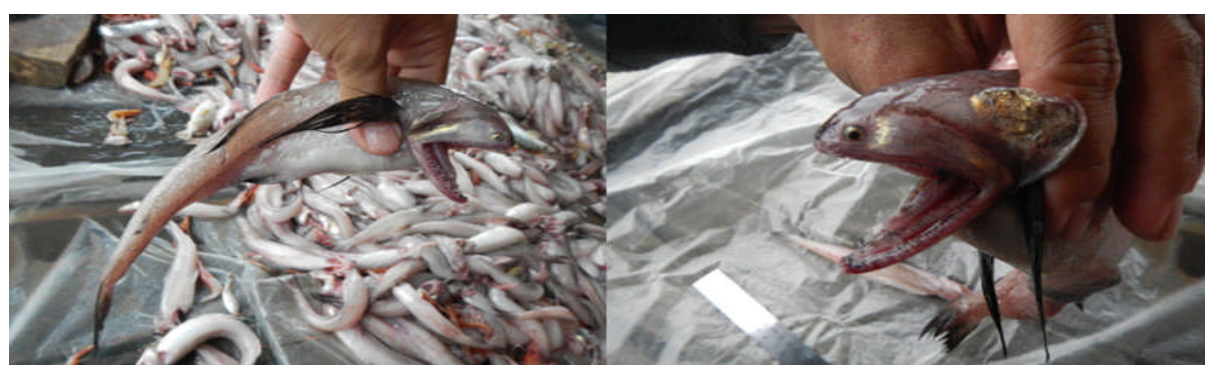

Figure 2. The object of research; Bombay duck (Harpadon nehereus), locally called Nomei or Pepija. 

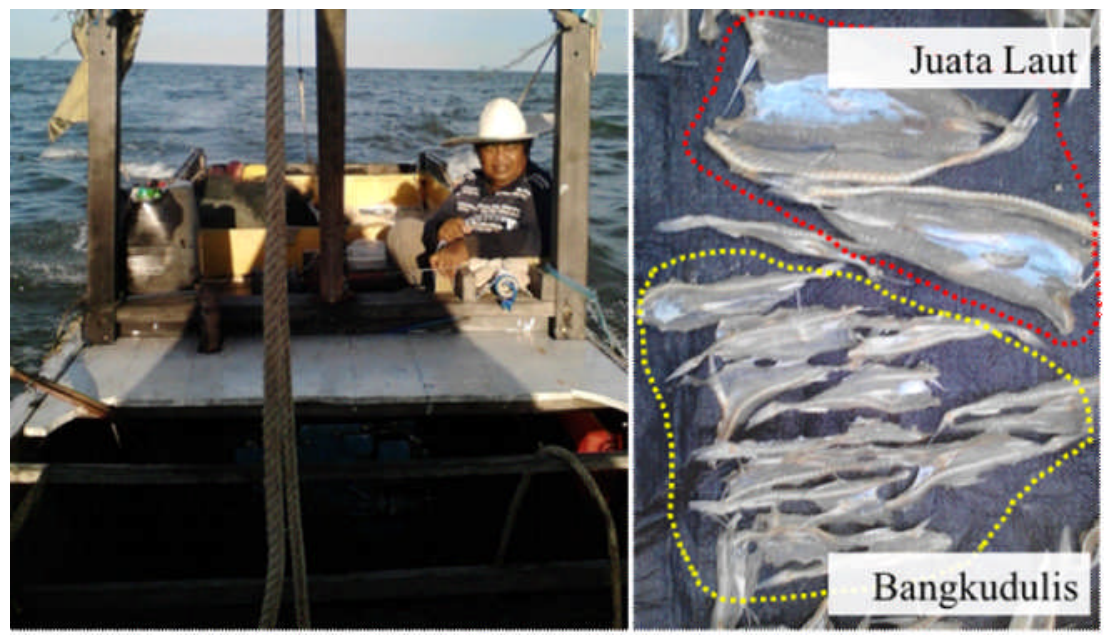

Figure 3. The trawlers (a) and size comparison between dried product of nomei in Bangkudulis waters (yellow dashed line) and Juata Laut waters (red dashed line) (b) (Courtesy of Dahlan 2014).

\section{Data Collection}

A bottom trawl and a hydro-acoustic were used to collect information on selected track (Figure 4) and then divided into 7 zones to examine the distribution of fish size. SIMRAD EY-60 used for acoustic data acquisition that equipped by GPT and transducer ES $120-7 \mathrm{C}$ which have frequency by $120 \mathrm{KHz}$ that has been setup to specific value (Table 1).

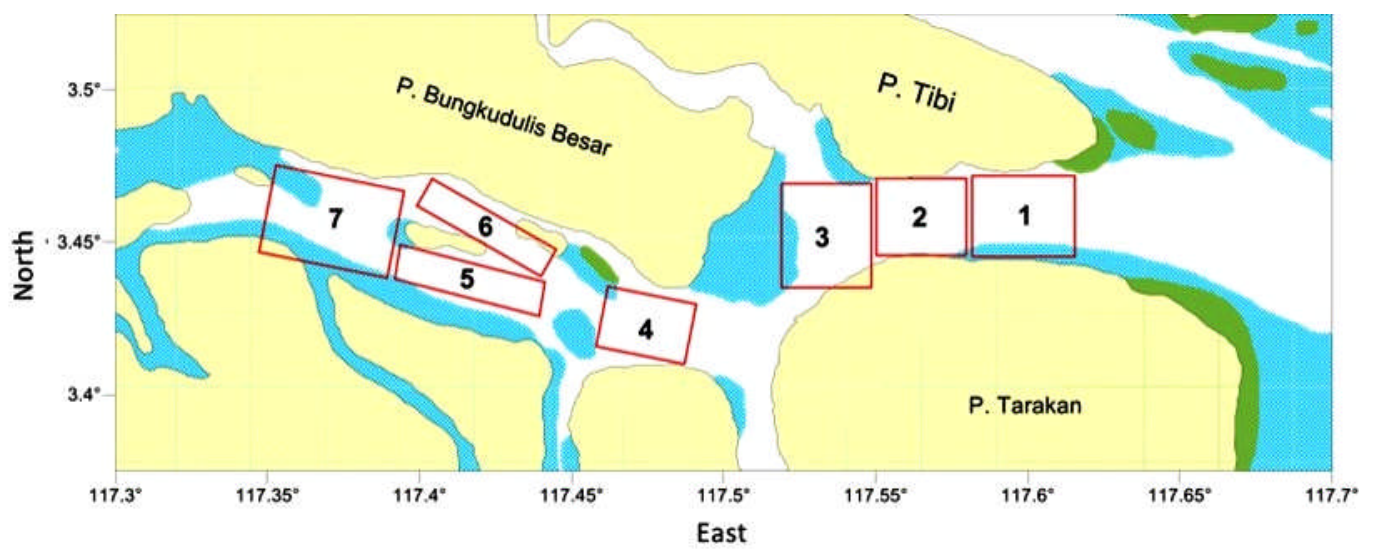

Figure 4. Location of research; zone for simplifying the analysis.

Table 1. Parameter of EY-60 during survey

\begin{tabular}{ll}
\hline Parameter & Value \\
\hline Frequency & $120 \mathrm{KHz}$ \\
Pulse Duration & $0.512 \mathrm{~ms}$ \\
Power transmit & 50 watts \\
Sound speed & $1,545 \mathrm{~m} / \mathrm{s}$ \\
Absorption Coef. & $38.52 \mathrm{~dB} / \mathrm{m}$ \\
SV threshold & $-70 \mathrm{~dB}$ \\
TS threshold & $-100 \mathrm{~dB}$ \\
\hline
\end{tabular}

Moreover, larvae samples were collected by using plankton-net (mesh size $200 \mathrm{im}$ ) equipped by flowmeter (to estimate filtered volume). The net setup on the stern side of vessel was towed for 5 minutes (2 replication). Samples were preserved using $10 \%$ of formaldehyde.

\section{Data Analysis}

Acoustic analysis was conducted about $5 \mathrm{~m}$ above seabed by setup back step $0.25 \mathrm{~m}$ to minimize echo integration from seabed (vonSzalay et al., 2007). It also considered the research target demersal fishes, 
especially Bombay duck. The Elementary Sampling Distance Unit (ESDU) was $0.1 \mathrm{~nm}$. The relationship between target strength (TS) and óbs (backscattering cross-section, $\mathrm{m}^{2}$ ) followed (MacLennan \& Simmonds, 1992) by TS $=10$ log óbs. The size composition showed in target strength $(\mathrm{dB})$ to explain horizontal and vertical distribution in respect of geographical position.

Sub-samples of larvae were collected in $5 \mathrm{ml}$ of container and place it in a "Bogorov" tray to examine taxonomic diversity after refiltered using 200 ìm sieve. Volume sample for macro-plankton-net was multiplied swept area of plankton-net $\left(0.75 \times 0.65=0.49 \mathrm{~m}^{2}\right)$ and transect distance ((difference in counts of flowmeter x 26,873)/999,999).

\section{RESULTS AND DISCUSSION Results}

\section{Target Strength Distribution}

The anecdotal information stated that in Bangkudulis waters inhabitant by juvenile fish of bombay duck. Bangkudulis waters are located in the estuarine in the northwest of Tarakan island by about $26.45 \mathrm{~km}$ (16.43 mil). During fishing season, fishers operated the trawler within 7-10 days. They operated in the Juata Laut waters (about $3.99 \mathrm{~km}$ from fisher settlement in Juata Laut, North Tarakan sub-district) and set about 3-5 hauling and made a loop in the waters. However, some fishers that excess the fishing period started to catch Bombay duck in the Bangkudulis waters. This fisher mostly conducted that by considering of low catch during fishing season in Juata Laut. In fact, they caught small sizes of bombay duck that have low value for middlemen. Moreover, it possibly disturbed the recruitment process that will affect next fishing season. The important thing that the proposed sanctuary area is the jurisdiction of Tana Tidung Regency, therefore the management measures should be taken to provincial level.

Acoustic survey revealed that in zone 1, 2 and 3 of Juata Laut waters, the modes of TS were -76, -77, and $-70 \mathrm{~dB}$, respectively. Moreover, TS value in zone 4 was found lower than in Juata Laut's zones by -83 $\mathrm{dB}$. However, that TS value was higher that the TS in zone inside the Bangkudulis waters $(5,6$ and 7$)$ by $88,-87$ and $-86 \mathrm{~dB}$, respectively. It also found the large schooling of small fishes $(-100$ to $-90 \mathrm{~dB})$ that were possibly the schooling of juvenile by considering the TS value (Figure 5). The comparison between the TS in Juata Laut and Bangkudulis waters shows the TS mode of Bangkudulis was lower that Juata Laut (Figure 6).

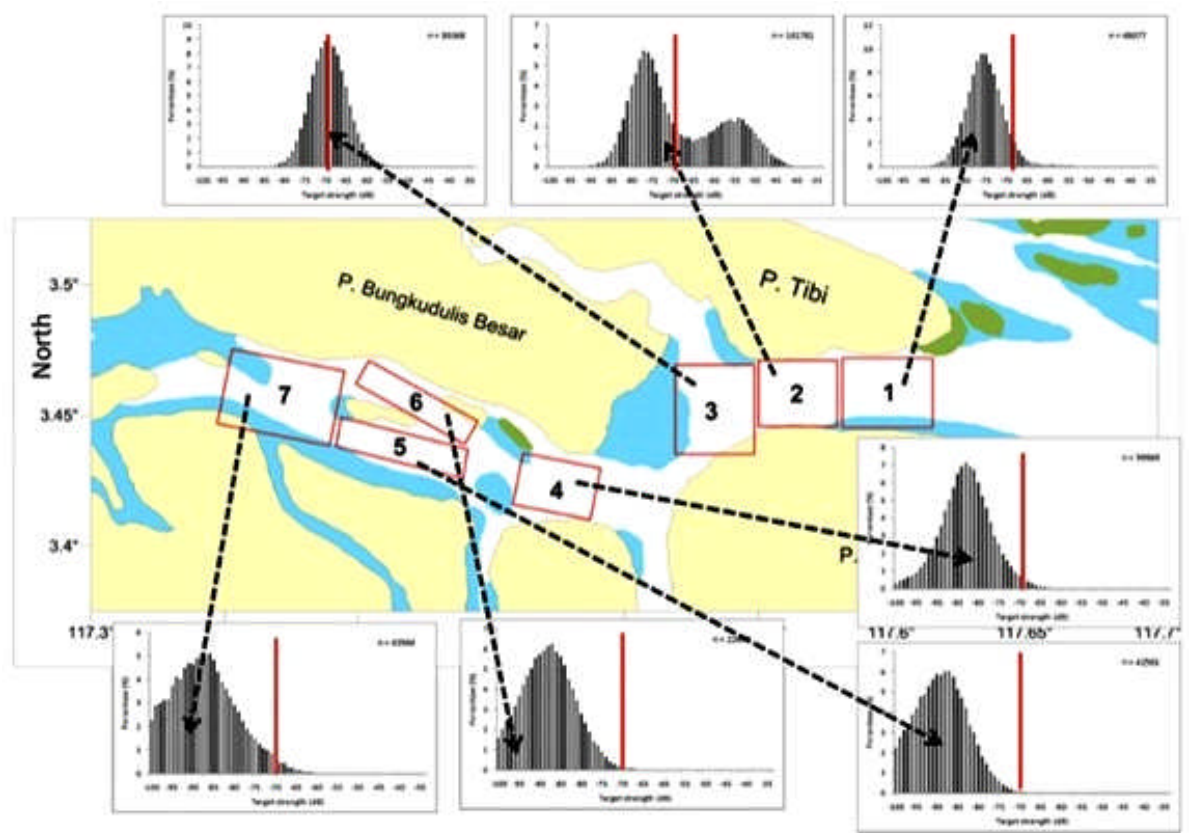

Figure 5. The distribution of TS value for Bombay duck in the Bangkudulis (station 4-7) and Juata Laut (station 1-3). 


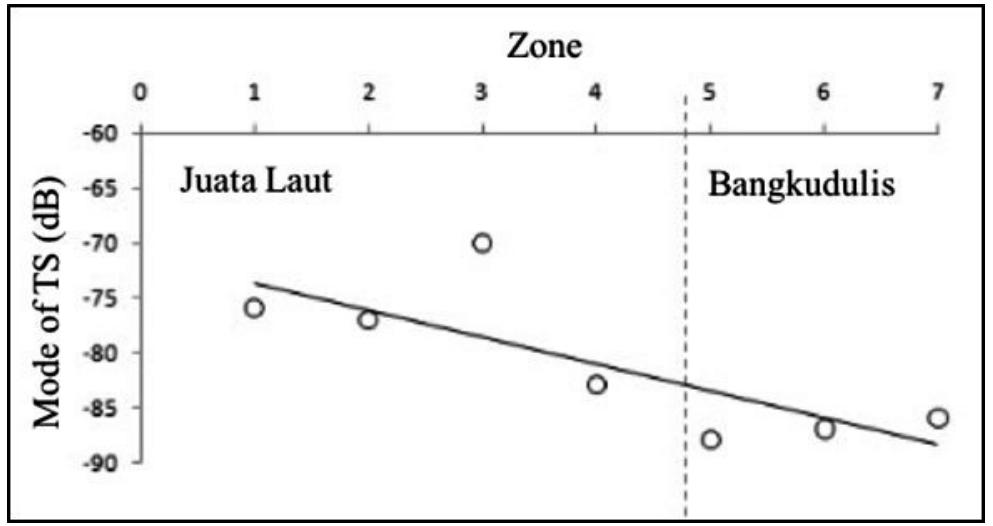

Figure 6. The comparison of TS distribution between inside (Bangkudulis) and outside (Juata Laut) of proposed sanctuary area.

\section{Size Frequency Distribution}

Trawl survey also found that in Juata Laut waters consist of relatively large size fishes compared to catches from Bangkudulis waters (Figure 7). Bombay duck caught in Juata Laut and Bangkudulis waters ranged from 18-27 cmFL and 11.7-22.5 cmFL, respectively. This finding aligned with a result of acoustic survey found in high concentration of small size fishes in the Bangkudulis waters.

\section{Larvae Distribution}

Plankton-net sampling also revealed high concentration of bombay duck's larvae in the Bangkudulis waters, especially in the northern station (Figure 8 ). There were 5 stations of 8 stations that contained bombay duck larvae. The highest concentration was found in station 6 (near Tibi Besar Island) by 6 individu/ml.
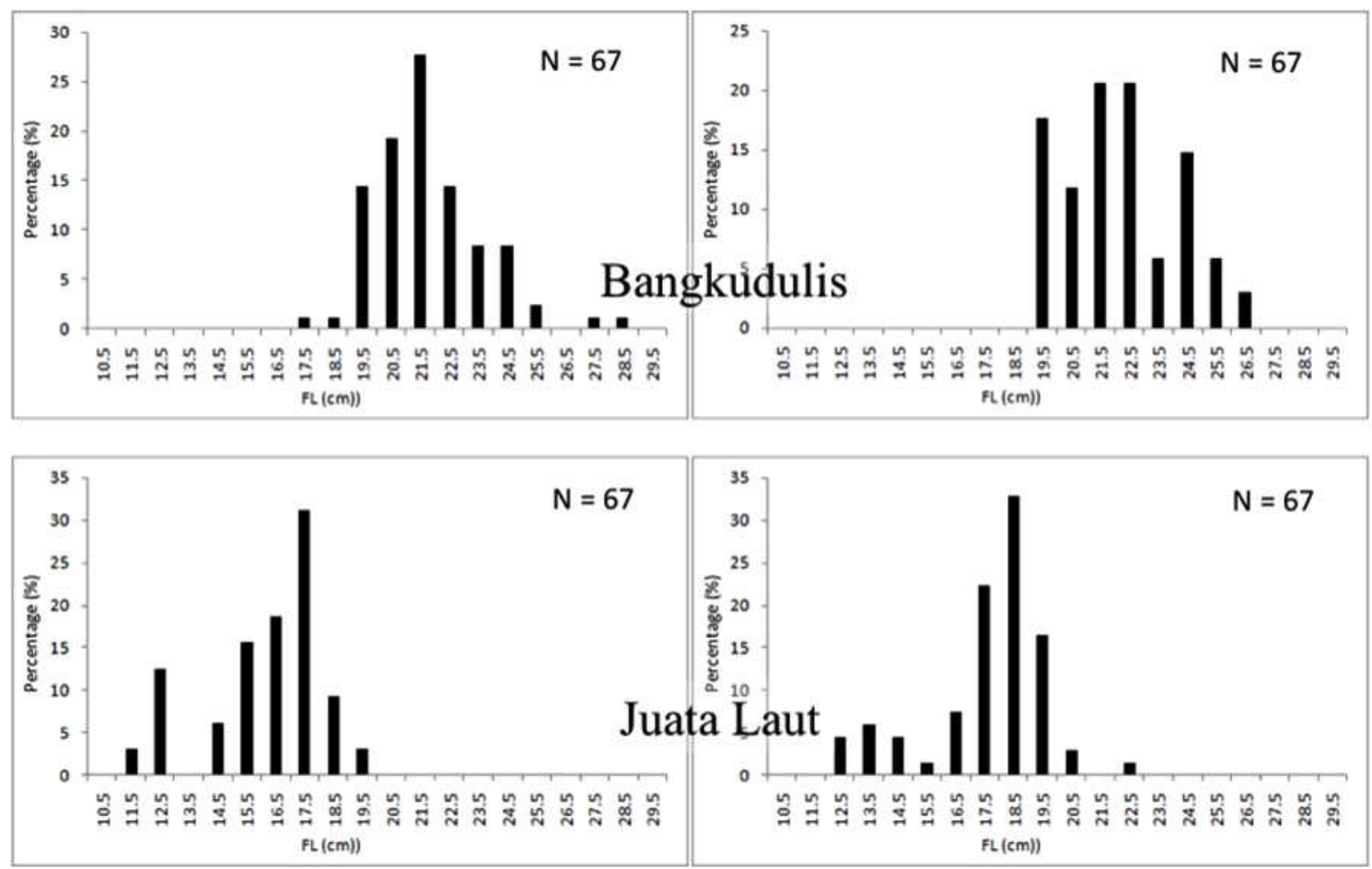

Figure 7. Size distribution of Bombay duck caught by trawl in Bangkudulis (above) and Juata Laut (Below) water. 


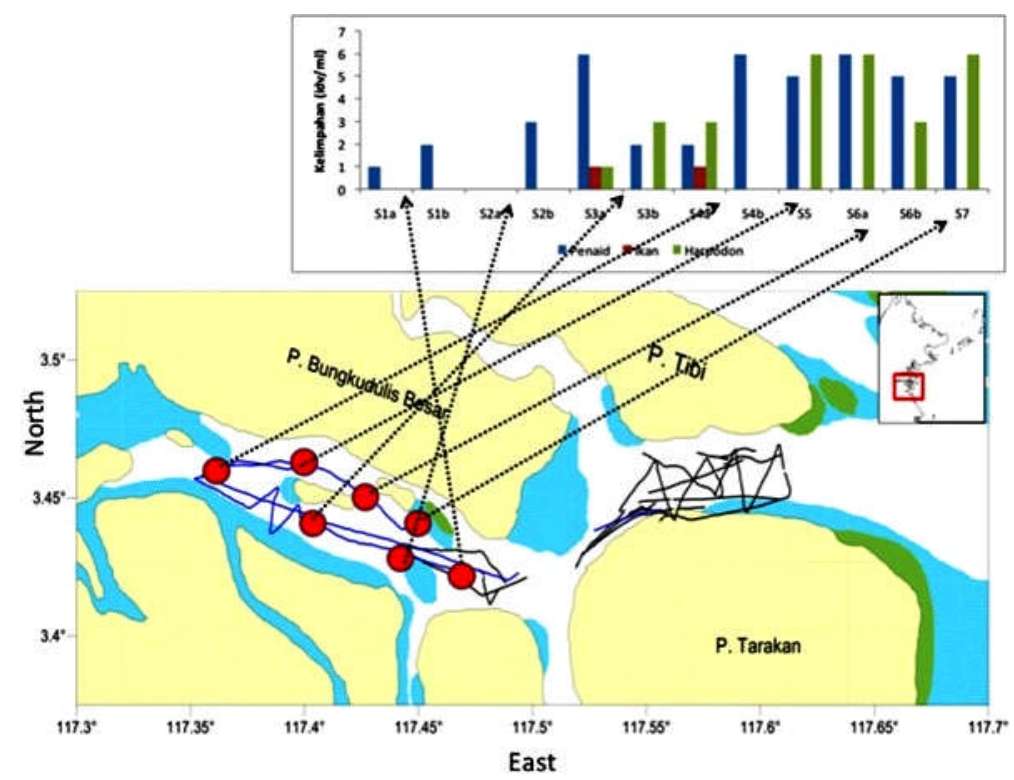

Figure 8. The larvae concentration in the Bangkudulis waters.

\section{Discussion}

The high exploitation rate of this resources which indicated over exploitation (Laga, 2015; Nugroho et al., 2015). Nugroho et al. (2015) used Spawning Potential Ratio (SPR) to examine the current SPR status of Bombay duck of $28 \%$. It is probably due to high fishing pressures to harvest this resource. It also suggested to adjust the minimum length at first capture (Lc) examined from $20.8 \mathrm{~cm}$ to $22.0 \mathrm{~cm}$ which could allow sustainable harvesting.

By considering the biological characteristics, this species has a fast growth rates that a minimum population doubling less than 15 months (Fishbase, 2015). Study showed that numbers of effort are densely operated in relatively narrow fishing grounds (Prasetyo et al., 2014). Therefore, a proper management measures should be taken into account to avoid worse scenario, such as effort reduction, temporal closure and spatial closure. It will allow the resource to be recover and ensure the long-term benefit for the community. Moreover, it also found that the trawl fisheries (targeting shrimp instead of Bombay duck) were only able to harvest about $30 \%$ of demersal fishes within swept area which turn out as catchability coefficient (q) (Priatna et al., 2014). So, about $70 \%$ of demersal fishes have a chance to avoid the harvest.

There is a rapid growth of studies on spatial closure planning methods and tools, but it has not been relatively well documented in Indonesian waters. Targeting of ecosystem services and consideration of land-sea connections were the emerging global issues that need to be taking into account on establishing MPA (Álvarez-Romero et al., 2013). The identification of critical habitat, such as a nursery and spawning ground are crucial in marine conservation planning (Dahlgren et al., 2006).

This research examined systematically process on establishing MPA for fisheries sanctuary that focus on bombay duck fisheries. It started to collect any available information from community through interview, literate study and focus group discussion (Prasetyo et al., 2014) to compromise the multiple social and biological objectives (Christie, 2004). It also acknowledged traditional knowledge of community to attempt scientific activities. This is important and also cutting-edge the process as well as build strong relationship with community. An ethnobiology is one of potential approach to strengthen local wisdom using scientific method, it will ensure an effective and efficient fisheries management based on community initiative (Oktaviani et al., 2016). Prescott et al. (2016) found that a strong engagement with fishers has benefit for effective monitoring of the resources. It also realized the hidden and valuable information from the fishers to the fisheries that enriched the scientific findings and minimize the uncertainty.

Bangkudulis waters are a potential nursery ground for bombay duck. It implied that, the size of fishes to the westward became small by examining the TS distribution. This area was firstly identified by interviewing the community's elder and doing analysis in the serial focus group discussion. The forum agreed to establish fisheries sanctuary as a fisheries management tool (Prasetyo et al., 2014). A larvae survey also determined the similar finding which showed high concentration of bombay duck's larvae in the Bangkudulis waters. By having fisheries 
sanctuary, it probably secures the potential recruitment to the fisheries (Álvarez-Romero et al., 2013; Botsford et al., 2009; Dahlgren et al., 2006; Fogarty \& Botsford, 2007; vonSzalay et al., 2007). It also proved the anecdotal information that stated Bangkudulis waters were the nursery ground of bombay duck.

This finding should be a vital basis to support local regulation. Since the proposed sanctuary area was a jurisdiction of Tana Tidung Regency, therefore Tarakan city does not have authority to manage it. Therefore, a higher authority should take apart which was North Kalimantan Province which was previously merged to East Kalimantan Province. Based on proper communication and strong engagement with local community and government, government established 3 regulation products, namely Marine and Fisheries Committee as communication forum for management (Mayor Decree No. 523/HK-XI/381/2014), local regulation established to support conservation of bombay duck fisheries i.e. Governor Decree of North Kalimantan Province No. 26 in 2014 and Mayor Decree of Tarakan City No. 24 in 2014. It proved the importance of regulation to support the effectiveness of MPA establishment (Mous et al., 2005).

\section{CONCLUSION}

It could be stated that the proposed conservation area of Bangkudulis waters has significant ecological function to ensure the sustainability of bombay duck population. It considered that high concentration of small size fishes in that area showed by acoustic, trawl and larvae survey. This research succeeds to initiate effort in recognizing local knowledge into empirical information. It also suggests the importance of local knowledge to engage the community into conservation action. By doing this, community will have strong bound in conservation measures that were developed through participatory communication.

\section{ACKNOWLEDGEMENTS}

The participating partners of UNOPS Project, "The Implementation of Tarakan East Kalimantan Demonstration Site of the SCS-SFMP' funded by GEF during 2012-2014; implement and executed by UNDP and UNOPS respectively. This research also supported by Research Institute for Marine Fisheries (RIMF) project, "Stock Assessment of Demersal Fish Resources in FMA 716 and FMA 712" in 2012. We wish to thank the many people who provide information for the field investigations. This includes staff of Research Institute for Marine Fisheries (RIMF),
Government Representative, and Port authorities, as well as fisher groups. Andhika Prima Prasetyo (APP) and Asep Priatna (AP) have equal contribution in preparing this manuscript.

\section{REFERENCES}

Álvarez-Romero, J. G., Pressey, R. L., Ban, N. C., Torre-Cosío, J., \& Aburto-Oropeza, O. (2013). Marine conservation planning in practice: lessons learned from the Gulf of California. Aquatic Conservation: Marine and Freshwater Ecosystems, 23, 483-505. doi:10.1002/aqc.2334

Botsford, L. W., Brumbaugh, D. R., Grimes, C.B., Kellner, J.B., Largier, J., O'Farrell, M.R., Ralston, S., Soulanille, E., \& Wespestad, V. (2009). Connectivity, sustainability, and yield: bridging the gap between conventional fisheries management and marine protected areas. Reviews in Fish Biology and Fisheries(19), 69-95. doi:10.1007/ s11160-008-9092-z.

Christie, P. (2004). Marine Protected Areas as Biological Successes and Social Failures in Southeast Asia. American Fisheries Society Symposium, 42, 155-164.

Crawford, B., Kasmidi, M., Korompis, F., \& Pollnac, R. B. (2006). Factors Influencing Progress in Establishing Community-Based Marine Protected Areas in Indonesia. Coastal Management, 34(1), 39-64. doi:10.1080/08920750500379300

Dahlgren, C. P., Kellison, G. T., Adams, A.J., Gillanders, B.M., Kendall, M.S., Layman, C.A., Ley, J.A., Negelkerken, I., \& Serafy, J.E. (2006). Marine nurseries and effective juvenile habitats: Concepts and applications. Marine Ecology Progress Series, 312, 291-295. doi:10.3354/ meps312291

Elliott, G., Mitchell, B., Wiltshire, B., Manan, A., \& Wismer, S. (2001). Community Participation in Marine Protected Area Management: Wakatobi National Park, Sulawesi, Indonesia. Coastal Management, 29(4), 295-316. doi:10.1080/ 089207501750475118

Fishbase. (2015). Bombay duck. Retrieved from http://www.fishbase.org/summary/260

Fogarty, M. J., \& Botsford, L. W. (2007). Population connectivity and spatial management of marine fisheries. Oceanography, 20, 112-123. 
Halpern, B. S. (2003). The impact of marine reserves: do reserves work and does reserve size matter? Ecological Applications, 13. doi:10.1890/10510761(2003)013[0117:TIOMRD]2.0.CO;2

Halpern, B. S., Regan, H. M., Possingham, H. P., \& McCarthy, M. A. (2006). Accounting for uncertainty in marine reserve design. Ecology Letters, 9, 2 11. doi:10.1111/j.1461-0248.2005.00827.x

Laga, A. (2015). Kajian ekobiologi ikan pepija (harpadon nehereus, hamilton 1822) sebagai dasar pengelolaan berkelanjutan di perairan pulau Tarakan (Doctoral), Institut Pertanian Bogor, Bogor.

Laga, A., Affandi, R., Muchsin, I., \& Kamal, M. M. (2015). Distribusi Spasial dan Temporal Ikan Pepija, Harpadon nehereus (Hamilton, 1822) di Perairan Pulau Tarakan, Kalimantan Utara. Zoo Indonesia, 24(1), 41-52.

MacLennan, D., \& Simmonds, E. J. (1992). Fisheries Acoustics. Netherlands: Springer.

Mous, P. J., Arifin, Z., et al. (2005). Policy needs to improve marine capture fisheries management and to define a role for marine protected areas in Indonesia. Fisheries Management and Ecology, 12, 259-268. doi:10.1111/j.1365-2400.2005.00448.x

Nugroho, D., Faizah, R., P.Prasetyo, A., \& Badrudin, M. (2015). Bio-exploitation status of bombay duck (harpodon nehereus hamilton, 1822) on trawl fishery in Tarakan waters. Ind.Fish.Res.J., 21(1), 53-59. doi:10.15578/ifrj.21.1.2015.53-59
Oktaviani, D., Prianto, E., \& Puspasari, R. (2016). Penguatan kearifan lokal sebagai landasan pengelolaan perikanan perairan umum daratan di Sumatera. J.Kebijak.Perikan.Ind., 8(1), 1-12. doi:10.15578/jkpi.8.1.2016.1-12

Prasetyo, A. P., Nugroho, D., Wudianto, Irianto, H. E., \& Purwanto. (2014). Initiation on Ecosystem Approach to Fisheries Management (EAFM): Case Study on Tarakan Fisheries. Ind.Fish.Res.J., 20(2), 87-98. doi:10.15578/ifrj.20.2.2014.87-98

Prescott, J., Riwu, J., Stacey, N., \& Prasetyo, A. (2016). An unlikely partnership: fishers' participation in a small-scale fishery data collection program in the Timor Sea. Reviews in Fish Biology and Fisheries, 26(4), 679-692. doi:10.1007/s11160015-9417-7

Priatna, A., Purbayanto, A., Simbolon, D., \& Hestirianoto, T. (2014). Kemampuan tangkap jaring trawl terhadap ikan demersal di perairan tarakan dan sekitarnya. J.Lit.Perikan.Ind., 20(1), 19-30. doi:10.15578/jppi.20.1.2014.19-30

vonSzalay, P. G., Somerton, D. A., \& Kotwicki, S. (2007). Correlating Trawl and Acoustic Data in the Eastern Bering Sea: A First Step Toward Improving Biomass Estimates of Walleye Pollock (Theragrachalcogramma) and Pacific cod (Gadus macrocephalus). Fisheries Research, 86(1), 7783. doi:10.1016/j.fishres.2007.05.005

Wood, L. J., Fish, L., Laughren, J., \& Pauly, D. (2008). Assessing progress towards global marine protection targets: shortfalls in information and action. Oryx(42), 340-351. doi:10.1017/ S003060530800046X 